\title{
Development of Transgenic indica Rice with a Chimeric cry $2 A X 1$ Gene against Leaffolder, Cnaphalocrocis medinalis (Guenee)
}

\author{
G. Rajadurai ${ }^{1}$, S. Varanavasiyappan ${ }^{2}$, N. Balakrishnan ${ }^{2}$, V. Udayasuriyan ${ }^{2}$, \\ D. Sudhakar ${ }^{2}$ and N. Natarajan ${ }^{1 *}$ \\ ${ }^{1}$ Department of Agricultural Entomology, ${ }^{2}$ Department of Plant Biotechnology, \\ Agricultural college and Research Institute, Tamil Nadu Agricultural University, \\ Coimbatore -641003, India \\ *Corresponding author
}

\section{A B S T R A C T}

\section{Keywords}

Transgenic rice, cry $2 A X 1$ gene, Protein expression, Insect resistance, Leaf folder

Article Info

Accepted:

24 June 2018

Available Online:

10 July 2018
The insecticidal chimeric cry $2 A X 1$ gene was introduced into rice indica cultivar ASD16 with a view to impart resistance to a major lepidopteran pest, rice leaf folder. A total of 17 putative transgenic events were generated with two different constructs harbouring $c r y 2 A X I$ gene and all of them were found to be positive for cry $2 A X 1$ and hptII genes. The Cry $2 \mathrm{AX} 1$ protein expression in $\mathrm{T}_{0}$ transgenic rice events ranged from 0.021 to $0.093 \mu \mathrm{g} / \mathrm{g}$ of fresh leaf tissue. The detached leaf bit bioassay on selected transgenic plants against neonates of Cnaphalocrocis medinalis showed that the larval mortality ranged from 23.33 to 66.67 per cent in $\mathrm{T}_{0}$ transgenic plants.

\section{Introduction}

Rice leaffolder, Cnaphalocrocis medinalis (Guenee) (Lepidoptera: Pyralidae), is considered as a major pest of rice in some parts of the world especially in South Asia. The insect is spread throughout Taiwan, Japan, Korea, China, Southeast Asia, India, Australia, and Africa (Khan et al., 1989). The larval stage of the insect folds the leaf blade by attaching leaf margin together and feeds inside the folded leaf by scrapping the green content of the leaf, resulting in reduced photosynthesis which in turn leads to reduction in yield (Fraenkel and Fallil, 1981; Khan et al., 1989). Large scale cultivation of high yielding varieties and the accompanying changes in cultural practices are very conducive to leaf folder infestation (Dale, 1994; Senthil Nathan et al., 2004). Yield loss caused by this pest has been recorded between 63 and 80 per cent in rice (Rajendran et al., 1986; Murugesan and Chelliah, 1987; Prabal and Saiki, 1999). A large amount of insecticides are used for controlling the pest which leads to increase in the cost of 
production and poses risk to environment and human health (Pingali and Roger, 1995; Matteson, 2000). All the existing commercial rice varieties have became susceptible and it is highly imperative to find out resistant donor in rice germplasm (Rehman et al., 2005).

Introduction of insect-resistance genes into crop plants through gene transfer technology would be a sustainable alternative to the extensive use of chemicals (Maqbool et al., 2001). Bacillus thuringiensis (Bt) gene is the most effective insecticidal gene as on date and being widely used in insect resistant transgenic crops. The first transgenic rice plant with insect resistant Bt protein was reported by Fujimoto et al., (1993). Thereafter, many transgenic rice varieties have been transformed with cry genes and shown to be resistant against major lepidopteran pests (Nayak et al., 1997; Tu et al., 2000; Ye et al., 2003; Ramesh et al., 2004; Bashir et al., 2005; Xia et al., 2011; Yang et al., 2014; Wang et al., 2014).

However, the continuous use of cry toxins against a target insect pest leads to breakdown of resistance and such resistance development in insects is a major concern. However, resistance developed by an insect against one protein (Cry1A) are not cross-resistant to another (Cry2A) protein (Tabashnik et al., 2000). So, pyramiding of two or more genes with different modes of action, is one of the strategies employed to delay the resistance development in insects.

In our centre, a novel chimeric $B t$ gene cry $2 A X 1$ was developed by using the sequences of cry $2 A a$ and $c r y 2 A c$ cloned from indigenous isolates of $B t$ (Udayasuriyan et al., 2010), and reported to be toxic against Helicoverpa armigera and Spodoptera litura in tobacco (Udayasuriyan, 2012; Jayaprakash et al., 2014), tomato (Balakrishnan et al., 2012), against leaffolder in rice (Manikandan et al., 2014 and 2016) and yellow stem borer, leaffolder and oriental army worm (Chakraborty et al., 2016).

In present study, we report the development of transgenic rice with indica cultivar ASD16 expressing cry $2 A X 1$ which exhibit significant level of resistance against the rice leaffolder, C. medinalis.

\section{Materials and Methods}

\section{Plant transformation vector and cultures}

A chimeric cry $2 A X 1$ gene driven by maize ubiquitin promoter and nos terminator was cloned into $\mathrm{pUH}$ vector (Katiyar-Agarwal et $a l ., 2002)$ with BamHI and KpnI restriction sites (Figure 1a). Similarly, cry $2 A X 1$ gene driven by fused $r b c S$ promoter with its transit peptide and nos terminator was cloned into pCAMBIA1300 vector with HindIII and SalI restriction site (Figure 1b). Hygromycin phosphotransferase (hpt) gene was used as a plant selectable marker. The construct was mobilized into Agrobacterium strain, LBA4404 through triparental mating and used in rice transformation experiments.

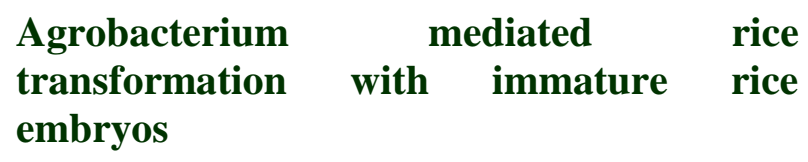

Agrobacterium-mediated rice transformation protocol was followed as suggested by Hiei and Komari (2008). Two day old bacterial culture were suspended in AA infection medium with $50 \mu$ Macetosyringone for rice transformation. About fourteen day old immature seeds of rice indica cultivar ASD16 were collected from the rice field maintained at Paddy Breeding Station, TNAU, Coimbatore. About fourteen day old healthy immature seeds of rice (Oryza sativa L.) indica var. ASD16were collected from field and dehusked. For surface sterilization, 
dehusked immature seeds were pre-rinsed with $70 \%$ ethanol for $1 \mathrm{~min}$ followed by $0.1 \%$ mercury chloride for $3 \mathrm{~min}$ and three times wash with sterile distilled water. Isolated healthy immature embryos were transferred into sterile Eppendorf tubes containing sterile water and incubated at $43^{\circ} \mathrm{C}$ for $30 \mathrm{~min}$ in water-bath followed by one min incubation on ice. The content was centrifuged at 1,100 rpm for $10 \mathrm{~min}$. The pre-treated immature embryos were placed on cocultivation medium containing $100 \mathrm{~m}$ Macetosyringoneby scutellum facing up and $5 \mu \mathrm{l}$ of the Agrobacterium suspension was added onto each embryo and incubated at $26^{\circ} \mathrm{C}$ in dark for $30 \mathrm{~min}$. Infected embryos were transferred to fresh place on the same plate and incubated at $26^{\circ} \mathrm{C}$ in dark for seven days. Putative embryogenic calli from co-cultivated immature embryos were separated from the elongated shoots and sub-cultured on resting medium containing $250 \mathrm{mg} \mathrm{l}^{-1}$ cefotaxime for 15 days at $31{ }^{\circ} \mathrm{C}$ under continuous illumination. The proliferated embryogenic calli were sub-cultured on selection medium containing hygromycin $50 \mathrm{mg} 1^{-1}$ and $250 \mathrm{mg}$ $1^{-1}$ cefotaxime for 17 days and selected calli were transferred to pre-regeneration medium containing hygromycin $40 \mathrm{mg} \quad 1^{-1}$ and incubated at $31^{\circ} \mathrm{C}$ for 7 days with continuous illumination. The proliferated calli with green spots were sub-cultured on regeneration medium containing $30 \mathrm{mg} \mathrm{l}^{-1}$ hygromycin. The regenerated plantlets were transferred to half strength of MS medium containing $30 \mathrm{mg} \mathrm{l}^{-}$ ${ }^{1}$ hygromycin for rooting. Well developed putative plants were transferred to portray filled with soil and maintained in transgenic greenhouse for hardening (Figure 2).

\section{Polymerase chain reaction for transgene confirmation}

Plant genomic DNA was isolated from the putative transformants and wild type control plants by CTAB method (Dellaporta et al.,
1983). Presence of the cry $2 A X 1$ and hptII genes in transgenic plants were analysed with gene specific primers (for cry $2 A X 1$ gene: CryF- 5' - CCTAACATTGGTGGACTT CCAG - 3'; CryR - 5' - GAGAAACGAGCT CCGTTATCGT -3'; forhpt gene: HptF- 5' GACGTCTGTCGAGAAGTT - 3'; HptR - 5' - CCTCCAGAAGAAGATG - 3'). These primers amplify, 800 and 686bp internal fragment of cry $2 A X 1$ and hptII gene, respectively. Amplified PCR products were resolved in $0.8 \%$ agarose gel electrophoresis with ethidium bromide staining, which was visualized on UV transilluminator.

\section{Enzyme Linked ImmunoSorbant Assay for Cry2AX1 protein expression analysis}

The transgenic plants which showed positive amplification for cry $2 A X 1$ gene were subjected to Cry2AX1 protein expression analysis through ELISA.The quantitative ELISA kit (Envirologix, USA) was used for this assay as per the manufacturer's instructions. Fresh leaf tissues $(30 \mathrm{mg})$ of transgenic and non-transgenic rice samples were collected and homogenized with $500 \mu \mathrm{l}$ of extraction buffer (1X extraction buffer used from the kit) followed by centrifugation at $6000 \mathrm{rpm}$ for $7 \mathrm{~min}$ at $4^{\circ} \mathrm{C}$. Supernatant of 100 $\mu \mathrm{l}$ from the extract was used for the assay. Each treatment was replicated twice and the protein expression was calculated on a linear standard curve by using the standards provided in the kit. Cry2AX1 protein levels were expressed as $\mu \mathrm{g} / \mathrm{g}$ of fresh leaves.

\section{Detached leaf bit bioassay against rice leaf folder}

Adult moths and larvae of rice leaf folder were collected from the rice field and reared on $\mathrm{TN} 1$ rice plants maintained in insect cages $(65$ $\mathrm{cm}$ X $65 \mathrm{~cm} \mathrm{X} 75 \mathrm{~cm}$ ) and the adult moths was supplemented with $10 \%$ honey solution. The second generation neonates stage larvae 
of $C$. medinalis were used for the assay. About $5 \mathrm{~cm}$ long leaf bits from transgenic and nontransgenic ASD16 plants were placed in aplastic Petriplate $(90 \mathrm{~mm}$ dia.) containing moist filter paper. Thirty neonates (five larvae/ leaf bit) were included in each treatment. The experiment was done in three replications and maintained at $25 \pm 1{ }^{\circ} \mathrm{C}, 60 \%$ relative humidity for 6 days. The larval mortality was recorded on $6^{\text {th }}$ day of experiment and expressed in percentage.

\section{Results and Discussion}

Transgenic crops producing Bacillus thuringiensis (Bt) toxins kill the target insect pests and can significantly reduce reliance on insecticide sprays. The first commercialized Bt crops expressed a single Bt toxin of Cryl family which are effective against certain lepidopteran larvae and currently they are not in cultivation as insect pests have evolved resistance to $\mathrm{Bt}$ proteins expressed in Bt crops (Tabashnik et al., 2013). Sustainable use of such crops requires methods for delaying evolution of resistance by insect pests. To delay the pest resistance, second generation transgenic crops produce two different $\mathrm{Bt}$ toxins targeting the same insect pest. This "pyramiding" strategy is expected to work effectively when selection for resistance to one toxin does not cause cross-resistance to the other toxin. To gain the benefits of this approach, Cry toxins to be used in gene pyramiding must be selected based on different mechanisms of action against insects (Jurat-Fuentes et al., 2003). For instance, Bt toxin Cry2Ab from the Cry2family is used widely in combination with Cry1 toxins to kill lepidopteran larvae.

The most widely used pyramid is transgenic cotton producing $\mathrm{Bt}$ toxins CrylAc and Cry2Ab. Cross-resistance between these toxins was presumed unlikely because they bind to different larval midgut receptor
(Tabashnik et al., 2009). In order to identify a suitable and alternative gene belonging to cry2family, in our centre, we have developed a chimeric cry $2 A X 1$ gene which consists of sequences belonging to $\operatorname{cry} 2 A a$ and $\operatorname{cry} 2 A c$. The present study is an attempt to evaluate the efficiency of Cry2AX1 protein expressed in rice plants against a major pest of rice, rice leaffolder.

\section{Molecular confirmation of putative transgenic rice}

A chimeric cry $2 A X 1$ gene was transformed into immature embryo of ASD 16 rice cultivar through Agrobacterium mediated rice transformation. A total of 17 putative transgenic events were generated under hygromycin selection. The total genomic DNA isolated from the putative transgenic plants was subjected to PCR analysis for cry $2 A X I$ and hptII genes with their respective primers. Out of 17 transgenic plants regenerated from two constructs (7 putative events with $\mathrm{pUH}-u b i$-cry $2 A X 1$ and 10 putative events from $\mathrm{pC} 1300-r b c S$-tp-cry $2 A X 1)$, all the putative events were found to be positive for cry $2 A X 1$ and hptII genes with the amplification of 800 and $686 \mathrm{bp}$ internal sequences, respectively (Fig. 3a and 3b).

\section{Expression analysis of putative transgenic plants}

Five events generated with pUH-ubicry $2 A X 1$ had detectable level of Cry $2 \mathrm{AX} 1$ protein which ranged from 0.036 to $0.093 \mu \mathrm{g} / \mathrm{g}$ of fresh leaf tissue, whereas three events $r b c S$ tp-cry $2 A X 1$ had levels ranging from 0.021 to $0.039 \mu \mathrm{g} / \mathrm{g}$ of fresh leaf tissue (Table 1). The events, GR-ASD16-L5 and GR-ASD16-L6 had a maximum level of protein expression $(0.093 \mu \mathrm{g} / \mathrm{g}$ of fresh leaf tissue) while nontransformed ASD 16 plants did not show any detectable level of protein expression. Variation in levels of Cry2AX1 protein 
expression was observed in the events analysed. The site of integration of the gene could be one of the reasons for varying in protein expression. Similarly, variation in the levels of Cry protein expression was observed by earlier workers as well, with expression ranging from 0.059 to $1.34 \mu \mathrm{g} / \mathrm{g}$ of fresh leaf tissue (Manikandan et al., 2016; Chakraborty et al., 2016) in rice.

Toxicity of Cry2AX1 protein against $C$. medinalis

Four putative transgenic plants were tested against the neonates of $C$. medinalis to check the efficacy of Cry2AX1. The larval mortality ranged from 23.33 to 66.67 per cent, while non-transgenic ASD16 did not showed any larval mortality (Table 1). Among the transgenic event tested, GR-ASD16-L5 had maximum (66.67 per cent) larval mortality. There was a significant difference in development of surviving larvae on transgenic and control plants over a period of 6 days. The larvae fed on transgenic plants were found to best united with abnormal development (Figure 4). The low level of expression observed in the present study could provide only a moderate level of protection (23.33 to 66.67 per cent larval mortality) against the neonates of $C$. medinalis. Earlier reports suggest that the Cry2AX1 protein expressed in rice could provide better protection against leaffolder even at a low level of expression (Manikandan et al., 2014; Chakraborty et al., 2016).

Increasing the expression of Cry $2 \mathrm{AX} 1$ protein in rice plants was carried out by targeting to the chloroplast using a signal peptide sequence along with the gene of interest. One of the major concerns in using constitutive promoter is that the expression is throughout the plant which includes tissues which are not fed by insects. Compared with the temporal or spatial-specific expression, the constitutive expression of foreign proteins in transgenic plants may cause adverse effects, such as the metabolic burden imposed on plants for constant synthesis of foreign gene products and may increase the potential risk of resistance of the target insects to Bt toxin.

To reduce the risk of toxin production throughout the plants, several promoters have been used to drive the expression of the $\mathrm{Bt}$ gene in specific tissues. The $r b c S$ gene, which encodes the small subunit of ribulosebisphosphate carboxylase (Rubisco), is expressed only in leaf mesophyll cells. The expression of the $B t$ gene by tissue-specific promoters enhanced the rice resistance to insects. Kim et al., (2009) reported that use of $r b c S$ promoter with its transit peptide sequence in transgenic rice increased the crylAc transcript and protein level by 25 - fold and 100-fold, respectively. The insect resistant gene, crylC under rice $r b c S$ promoter was transformed into Zhonghua 11 (Oryza sativa L. ssp. japonica) and transgenic plants were resistant against yellow stem borer, striped stem borer and leaf folder (Ye et al., 2009). But the levels of Cry1C were undetectable in endosperm.

In this direction, this study was carried to express the cry $2 A X 1$ gene by green tissue specific rice $r b c S$ promoter and target the expressed Cry2AX1 protein to chloroplast using their own transit peptide and to study its efficacy in transgenic rice plants. Earlier workers reported the improved level of expression of foreign genes by targeting them to the chloroplast in transgenic tobacco, cotton and rice (Wong et al., 1992; Jang et al., 1999; Kim et al., 2009; Wu et al., 2011; Rawat et al., 2011). However, contrary to our expectations, the level of expression was relatively low in plants where cry $2 A X 1$ driven by $r b c S$ promoter and its chloroplast transit peptide sequence. These lines needed to be studied further in $T_{2}$ generation for the stability of expression. 
Table.1 Protein expression and insect bioassay on $\mathrm{T}_{0}$ transgenic rice events expressing cry $2 A X 1$ gene

\begin{tabular}{|c|c|c|c|c|}
\hline $\begin{array}{l}\text { Sl. } \\
\text { No. }\end{array}$ & Rice line & Construct & $\begin{array}{l}\text { Protein } \\
\text { concentration } \\
(\mu \mathrm{g} / \mathrm{g}) *\end{array}$ & $\begin{array}{l}\text { Larval } \\
\text { mortality }(\%)^{* * *}\end{array}$ \\
\hline 1. & GR-ASD16-L3 & pUH-ubi-cry $2 A X 1$ & $0.067 \pm 0.02$ & NT \\
\hline 2. & GR-ASD16-L5 & pUH-ubi-cry $2 A X 1$ & $0.093 \pm 0.02$ & $66.67 \pm 05.77(54.74)^{\mathrm{a}}$ \\
\hline 3. & GR-ASD16-L6 & pUH-ubi-cry $2 A X 1$ & $0.093 \pm 0.03$ & $63.33 \pm 05.77(52.73)^{\mathrm{ab}}$ \\
\hline 4. & GR-ASD16-L7 & pUH-ubi-cry $2 A X 1$ & $0.036 \pm 0.02$ & NT \\
\hline 5. & GR-ASD16-L9 & pUH-ubi-cry $2 A X 1$ & $0.091 \pm 0.18$ & $56.67 \pm 05.77(48.83)^{b}$ \\
\hline 6. & GR-ASD16-L10 & $\begin{array}{l}\mathrm{pC} 1300-r b c S-t p- \\
c r y 2 A X 1\end{array}$ & $0.021 \pm 0.02$ & NT \\
\hline 7. & GR-ASD16-L12 & $\begin{array}{l}\mathrm{pC} 1300-r b c S-t p- \\
c r y 2 A X 1\end{array}$ & $0.039 \pm 0.17$ & $23.33 \pm 05.77(28.88)^{\mathrm{c}}$ \\
\hline 8. & GR-ASD16-L13 & $\begin{array}{l}\mathrm{pC} 1300-r b c S-t p- \\
c r y 2 A X 1\end{array}$ & $0.034 \pm 0.10$ & NT \\
\hline 9. & ASD16 - Control & - & 0.00 & $0.00^{\mathrm{d}}$ \\
\hline \multicolumn{3}{|c|}{ SEd } & & 2.5815 \\
\hline \multicolumn{3}{|c|}{ CD $(0.05)$} & & 5.7520 \\
\hline
\end{tabular}

Values are arc sin transformed, mean of original value given in the table with \pm SD. NT- not tested. * - Two replications was maintained, **- Three replication was maintained.

Figure.1a T-DNA region of plant transformation construct $\mathrm{pUH}-u b i$-cry $2 \mathrm{AX} 1$

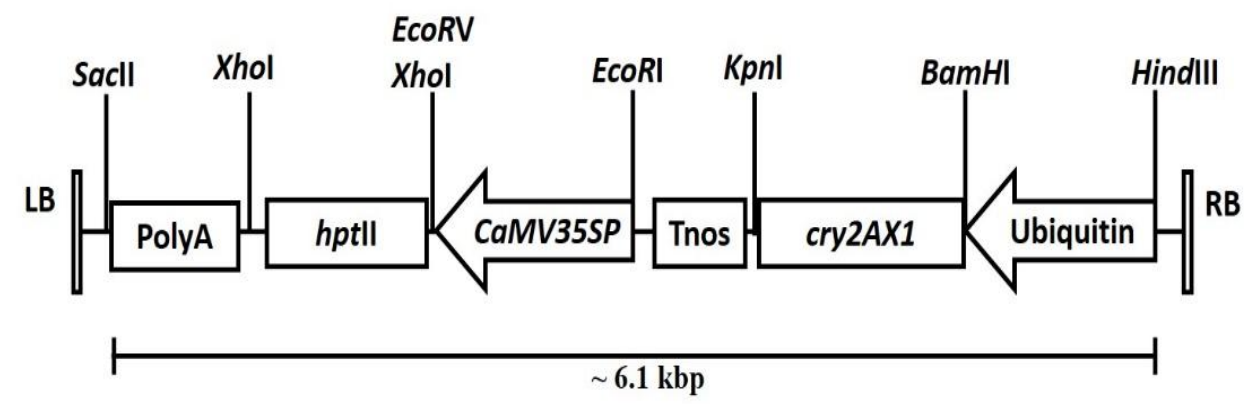

Figure.1b T-DNA region of plant transformation construct $\mathrm{pC} 1300-r b c S$ - $t p-2 A X 1$

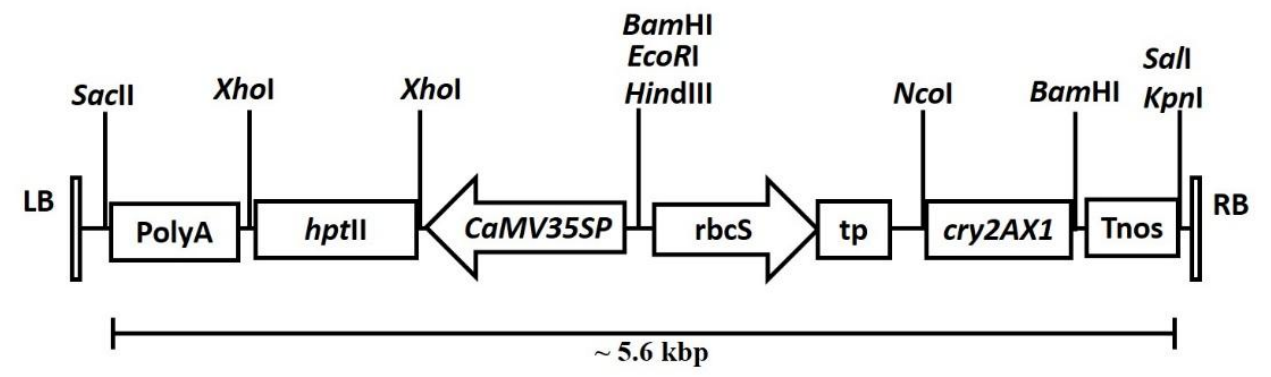


Figure.2 Agrobacterium mediated rice transformation with immature rice embryo

a

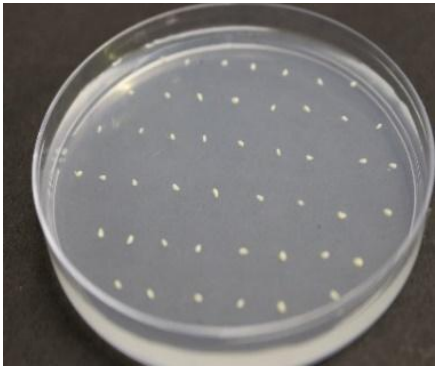

C

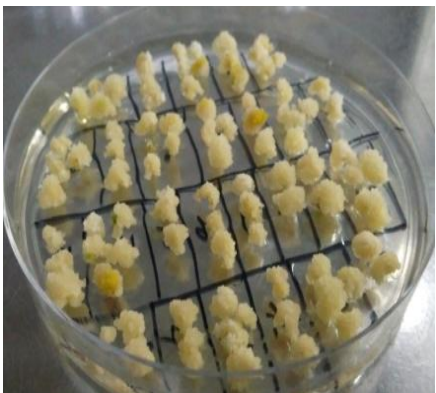

e

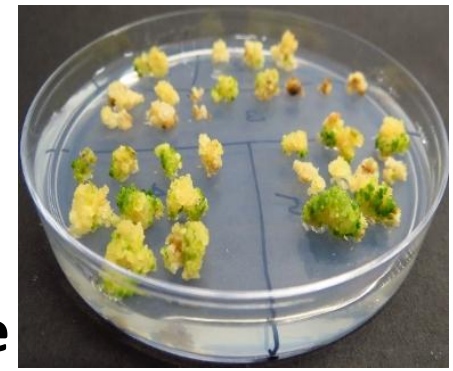

g

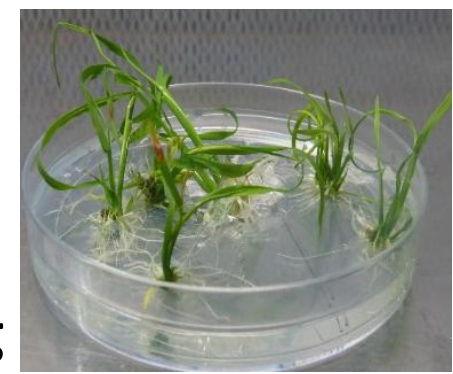

b

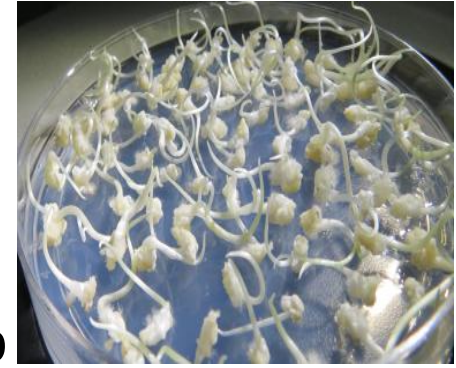

d

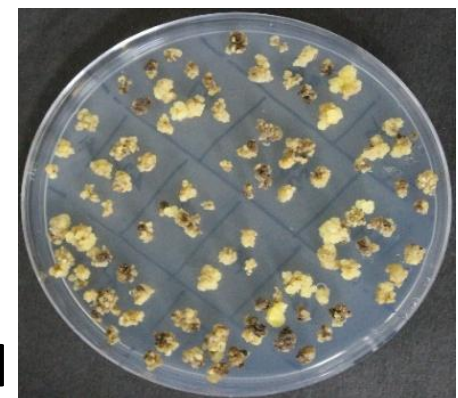

f

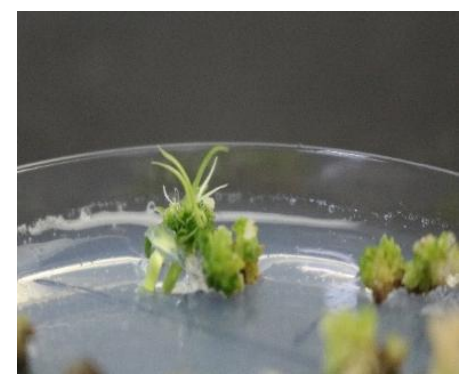

h

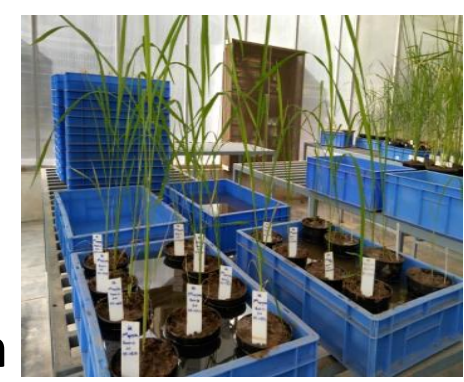

a. Pre-cultured rice immature embryos infected with Agrobacterium on NB-As medium

b. Immature embryos after co-cultivation on NB-As medium

c. Subcultured calli on resting medium (CCMC)

d. Subcultured calli on selection medium $(\mathrm{CCMCH} 50)$ after second round of selection

e. Embryogenic calli on pre-regeneration medium (NBPRH40)

f. Shoot development on regeneration medium (RNMH30)

g. Root Development on rooting medium (half strength MS medium)

h. Hardening of putative transgenic plants in transgenic greenhouse 
Figure.3a PCR analysis of putative transgenic $\mathrm{T}_{0}$ plants for presence of $\operatorname{cry} 2 A X 1$

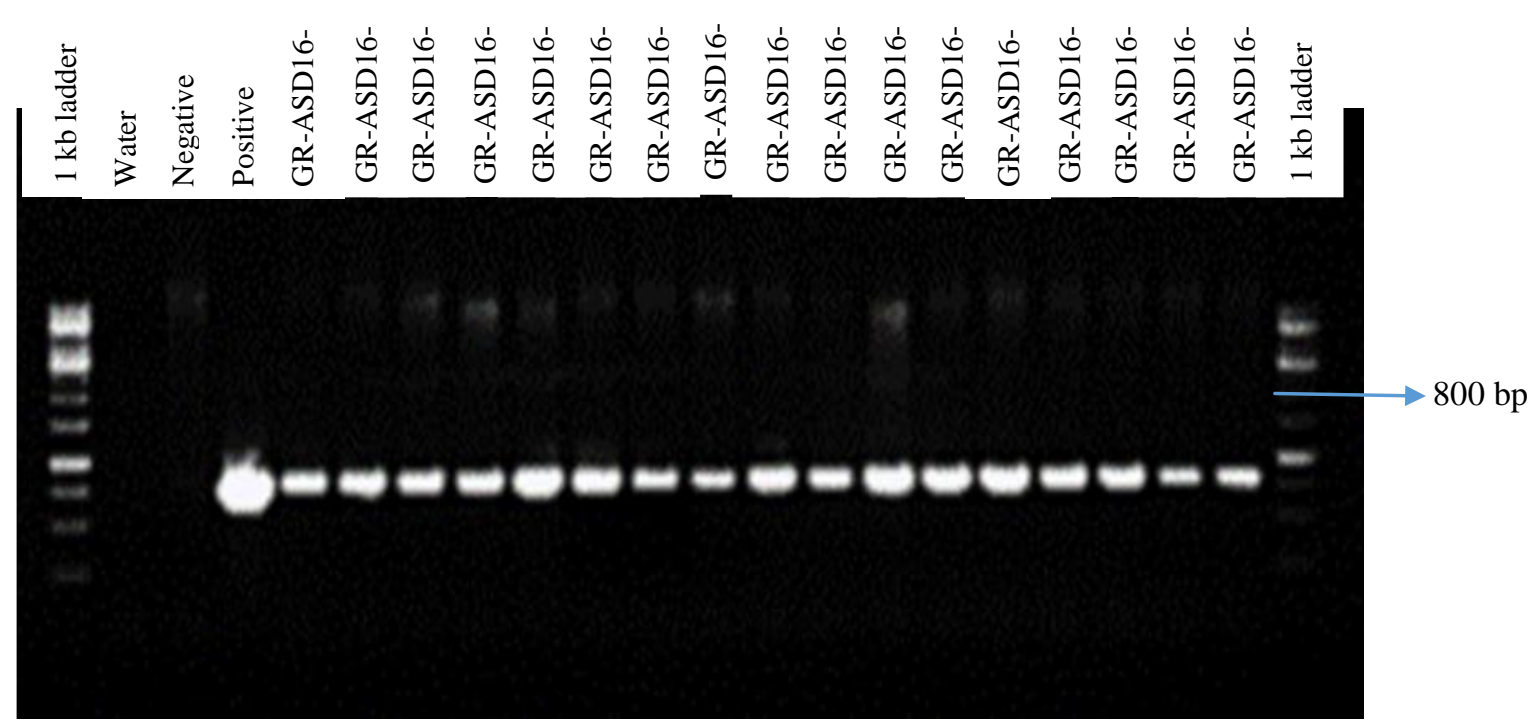

3a. A 800 bp internal sequence of cry $2 A X 1$ gene was amplified by PCR from the DNA isolated from putative transgenic plants. Lanes 1 and 22 1kb ladder, 4- Positive (plasmid of pC1300-rbcS-tp-cry2AXI), 2- Negative control (ASD16), 3 - Negative control (Water) and 5-21 - putative transgenic events.

Figure.3b PCR analysis of putative transgenic $\mathrm{T}_{0}$ plants for presence of $h p t I I$

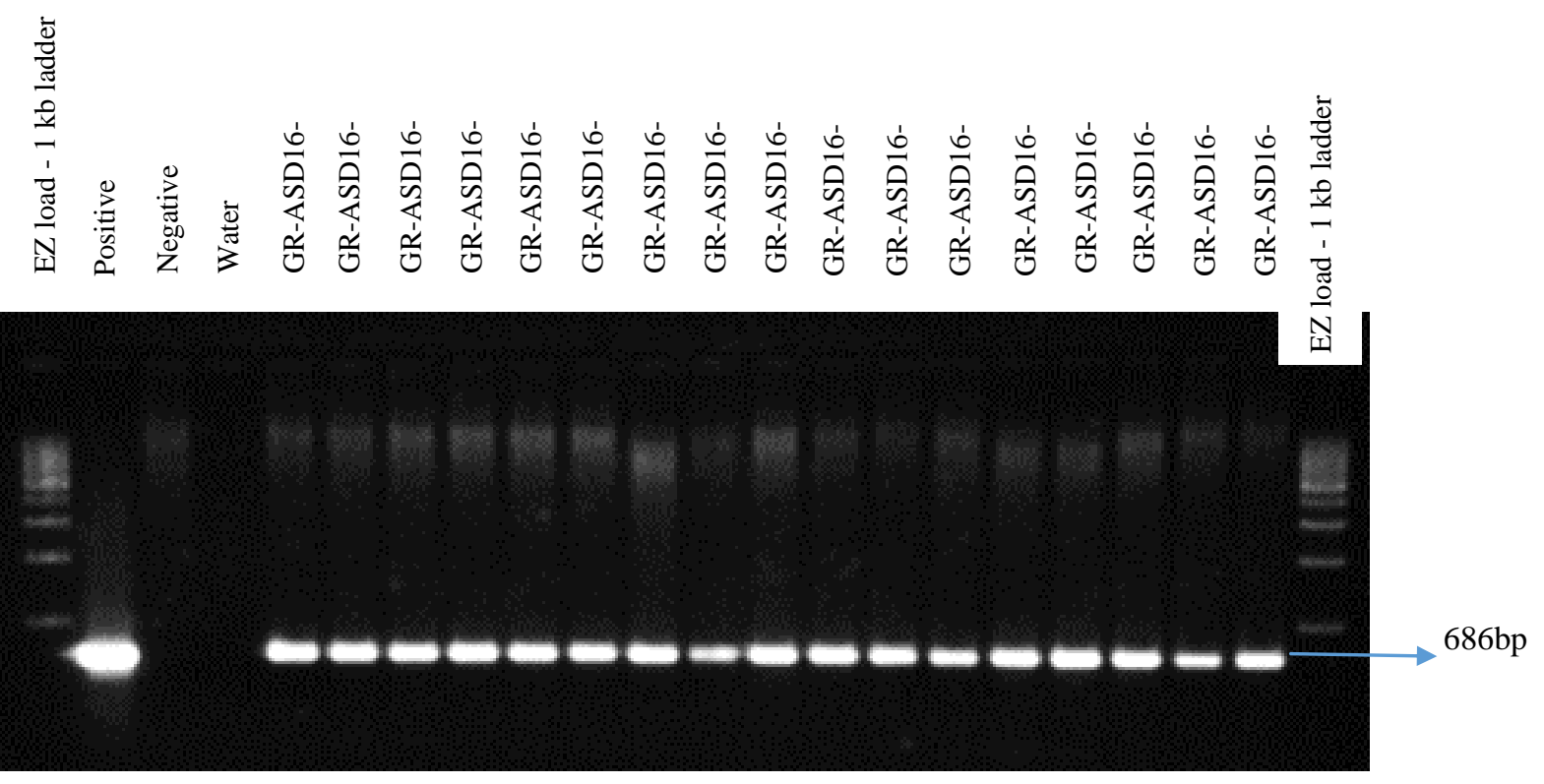

3b. A 686bp internal sequence of hptII gene was amplified by PCR from the DNA isolated from putative transgenic plants. Lanes 1 and 22 EZ load 1kb ladder, 2- Positive (plasmid of pC1300-rbcS-tp-cry2AX1), 3- Negative control (ASD16), 4- Negative control (Water) and 5-21 - putative transgenic events. 
Figure.4 In vitro insect bioassay on transgenic plants against neonates of rice leaffolder, $C$. medinalis
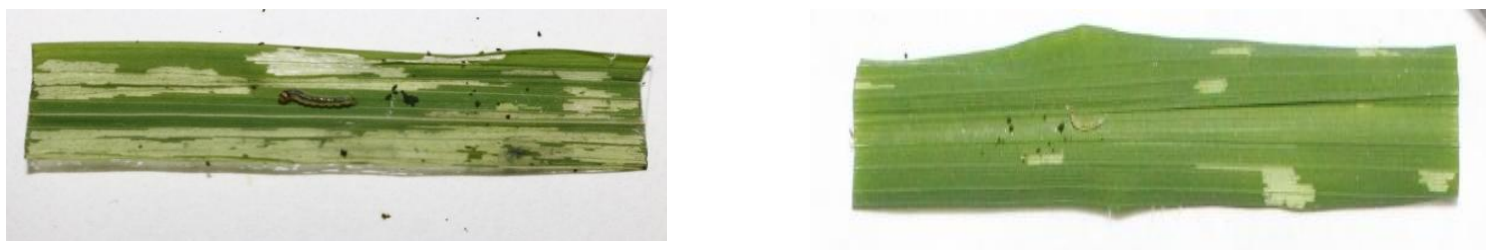

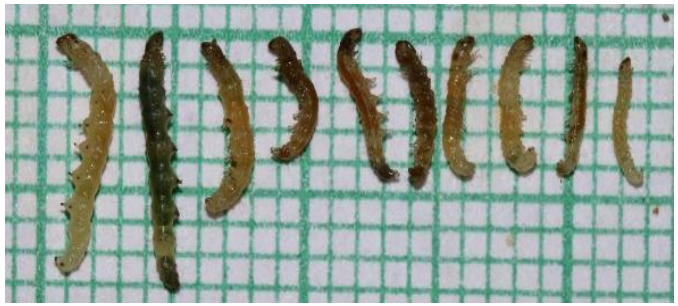

a.ASD 16 control

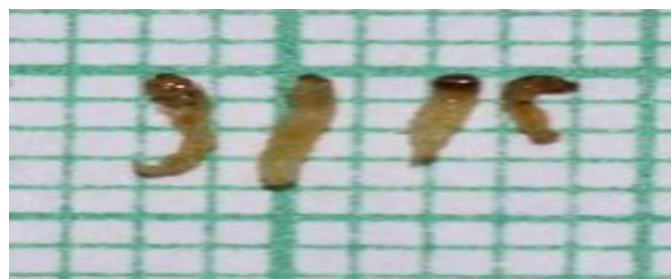

b. ASD16- Transgenic

a). Feeding symptom of leaffolder on ASD control plants and growth of surviving larvae; b). Feeding symptom of leaffolder on putative transgenic plants and growth of surviving larvae

It is concluded in the present study that the local cultivar ASD16 was transformed with cry $2 A X 1$ gene through Agrobacterium mediated transformation method by using the Agrobacterium strain, LBA4404. A total of 17 putative transgenic events were generated with two different constructs harbouringcry $2 A X 1$ gene and all of them found to be positive for the cry $2 A X 1$ and hptII genes. The expression level of Cry2AX1 protein is low and could provide moderate level of insect resistance with maximum of 66 per cent of larval mortality against neonates of $C$. medinalis. Developing large number of cry $2 A X 1$ transgenic rice lines is essential to identify transgenic rice plants with higher expression of target gene as well as insect resistance.

\section{References}

Balakrishnan, N., Ruturajrajan, B.,
Naveenkumar, A., Sozhavendan, A.E., Nandeesha, P., Illakkiyapriya, A., Balasubramani, V., Kumar, K.K., Sudhakar, D. and Udayasuriyan, V. 2012. Genetic transformation of tomato with cry $2 A X 1$ gene for resistance to fruit borer. In: Proceeding of 3rd world congress on biotechnology. Hyderabad international convention centre (HICC), Hyderabad, 13-15 Sept 2012.

Bashir, K., Husnain, T., Fatima, T.N., Riaz, N., Makhdoom,R. and Riazuddin, S. 2005. Novel indica basmati line (B-370) expressing two unrelated genes of $B$. thuringiensis is highly resistant to two lepidopteran insects in the field. Crop Prot, 24:870-879.

Chakraborty, M., Sairam Reddy, P., Mustafa, G., Rajesh, G., LaxmiNarasu, V. M., Udayasuriyan, V. and Debashis Rana. 2016. Transgenic rice expressing the cry $2 A X 1$ gene confers resistance to 
multiple lepidopteran pests. Transgenic Res.,25: 665-678.

Dale, D. 1994. Insect pests of the rice plant their biology and ecology. In: Biology and Management of Rice Insects (edited by E. A. Heinrichs). International Rice Research Institute/Wiley Eastern Limited, Los Banós/New Delhi. pp. 363-485.

Dellaporta, S.L., Wood, J. and Hicks, J.B. 1983. A plant DNA mini preparation: version II. Plant Mol. Biol. Rep., 1:1921.

Fraenkel, G. and Fallil, F. 1981. The spinning (stitching) behaviour of the rice leaffolder, Cnaphalocrocis medinalis. Entomo ExpAppl, 29(2): 138-146.

Fujimoto, H., Itoh, K., Yamamoto, M., Kyozuka, J. and Shimamoto, K. 1993. Insect resistant rice generated by introduction of a modified deltaendotoxin gene of Bacillus thuringiensis. Nat Biotechnol., 11:1151-1155.

Hiei, Y. and Komari, T. 2008. Agrobacterium-mediated transformation of rice using immature embryos or calli induced from mature seed. Nat. Protoc., 3:824-834.

Jang, I. C., Nahm, B. H. and Kim, J. K. 1999. Sub-cellular targeting of green fluorescent protein to plastids in transgenic rice plants provides a highlevel expression system. Mol. Breed., 5: 453-461.

Jayaprakash, S.P., Nandeesha, P., Sozhavendan, A.E., Naveenkumar, A., Illakiyapriya, A., Balakrishnan, N., Balasubramani, V., Singh, P.K., Sudhakar, D., Balasubramanian, P. and Udayasuriyan, V. 2014. Expression of a novel synthetic cry gene of Bacillus thuringiensis in transgenic tobacco confers resistance to Helicover paarmigera and Spodopteralitura. J. Pure Appl. Microbiol., 8(6):4687-4692.
Jurat-Fuentes, J.L., Fred L. Gould and Michael J. Adang. 2003. Dual Resistance to Bacillus thuringiensis Cry1Ac and Cry2Aa Toxins in Heliothis virescens suggests Multiple Mechanisms of Resistance. Applied and Environmental Microbiology, 6(10):5898-5906.

Katiyar-Agarwal, S., Kapoor, A. and Grover, A. 2002. Binary cloning vectors for efficient genetic transformation of rice. Curr. Sci., 82: 873-876.

Khan, Z.R., Rueda, B.P. and Caballero, P. 1989. Behavioural and physiological responses of rice leaffolder, Cnaphalocrocis medinalis to selected wild rices. Entomological Experimentalis et Applicata., 52:7-13.

Kim, E. H., Suh, S. C., Park, B. S., Shin, K. S., Kweon, S. J., Han, E. J., Park, S. H., Kim, Y. S. and Kim, J. K. 2009. Chloroplast targeted expression of synthetic Cry1Ac in transgenic rice as an alternative strategy for increased pest protection. Planta, 230: 397-405.

Manikandan R., Sathish, S., Balakrishnan, N., Balasubramani, V., Sudhakar, D. and Udayasuriyan, V. 2014. Agrobacterium mediated transformat-ion of indica rice with synthetic cry $2 A X 1$ gene for resistance against rice leaf folder. $J$. Pure Appl. Microbiol., 8(4):3135-3142.

Manikandan, R., Balakrishnan, N., Sudhakar,D. and Udayasuriyan, V. 2016. Transgenic rice plants expressing synthetic cry $2 A X 1$ gene exhibits resistance to rice leaffolder (Cnaphalocrosis medinalis). 3 Biotech, 6:10. DOI 10.1007/s13205-015-0315-4.

Maqbool, S.B., Riazuddin, S., Loc, N.T. Gatehouse, A.M.R., Gatehouse, J.A. and Christou, P. 2001. Expression of multiple insecticidal genes confers broad resistance against a range of different rice pests. Mol. Breed., 7: 8593. 
Matteson, P. C. 2000. Insect pest management in tropical Asian irrigated rice. Аnпи. Rev. Entomol., 45: 549 - 574.

Murugesan, S. and Chelliah, S. 1987. Yield losses and economic injury by rice leaf folder. Indian Journal of Agricultural Science, 56: 282-285.

Nayak, P., Basu, D., Das, S., Basu, A., Ghosh, D., Ramakrishnan, N.A., Ghosh,M. and Sen, S.K. 1997. Transgenic elite indica rice plants expressing CryIAc dendotoxin of Bacillus thuringiensis are resistant against yellow stem borer (Scirpophaga incertulas). Proc Natl Acad Sci., 94:2111-2116.

Pingali, P. L. and P. A. Roger. 1995. Impact of pesticides on farmer health and the rice environment. IRRI, Manila Philippines.

Prabal, P.S. and Saiki, P. 1999. Assessment of yield losses at different growth stages of stages of rice due to rice leaf folder, Cnaphalocrocis medinalis. Annals of Plant Protection Sciences, 7: 135-138.

Rajendran, R., Rajendran, S. and Sandra, B. P. C. 1986. Varietal resistance of rice to leaffolder. Int. Rice Res.Newsl.,11(4): 17-18.

Ramesh, S., Nagadhara, D., Reddy, V.D. and Rao, K.V. 2004. Production of transgenic indica rice resistant to yellow stem borer and sap-sucking insects, using super-binary vectors of Agrobacterium tumefaciens. Plant Science, 166: 1077-1085.

Rawat, P., Singh, A. K., Ray, K., Chaudhary, B., Kumar, S. V., Gautam, T., Kanoria, S., Kaur, G., Kumar, P., Pental, D. and Burma, P. K. 2011. Detrimental effects of expression of $\mathrm{Bt}$ endotoxin CrylAc on in vitro regeneration, in vivo growth and development of tobacco and cotton transgenics. J. Biosci., 36: 363-376.

Rehman, A., Saleem, M., Ramzan, M. and Akram, M. 2005. Some bio-ecological studies on leaffolder: A major pest of rice in Pakistan. In: Proceedings of International Seminar on rice. Kala Shah Kaku, 2-3 October, 2005, pp.262274.

Senthil Nathan, S., Chung, P. G. and Murugan,K. 2004. Effect of botanical insecticides and bacterial toxins on the gut enzyme of the rice leaf folder, Cnaphalocrocis medinalis. Phytoparasitica, 32(5): 433-443.

Tabashnik, B. E., Unnithan, G. C., Masson, L., Crowder, D. W., Li, X. and Carriere, Y. 2009. Asymmetrical cross-resistance between Bacillus thuringiensis toxins Cry1Ac and Cry2Abin pink bollworm. PNAS, 106(29): 11889-11894.

Tabashnik, B.E., Brévault, T. and Carrière, Y. 2013. Insect resistance to $B t$ crops: lessons from the first billion acres.Nat Biotechnol.,31: 510-521. doi: 10.1038/nbt.2597.

Tabashnik, B.E., Liu, Y.B., de Maagd, R.A. and Dennehy, T.J. 2000. Cross resistance of pink bollworm ( $P$. gossypiella) to $B$. thuringiensis toxins. Appl Environ Microbiol., 66:45824584.

Tu, J., Zhang, G., Data, K., Xu, C., He, Y., Zhang, Q., Khush, G.S. and Datta, S.K. 2000. Field performance of transgenic elite commercial hybrid rice expressing B. thuringiensisð-endotoxin. Nat. Biotechnol., 18:1101-1104.

Udayasuriyan, V. 2012. Efficacy of Cry2AX1 protein expressed in tobacco plants against Helicoverpa armigera and Spodoptera litura. In: International conference on plant biotechnology for food security (ICPBFS): frontiers, Volume: ST 28-poster presentation, 22 Feb 2012.

Udayasuriyan, V., IndraArulselvi, P., Balasubramani, V., Sudha, D.R., Balasubramanian, P. and Sangeetha, P. 2010. Construction of new chimeric cry $2 A X 1$ gene of $B$. thuringiensis 
encoding protein with enhanced insecticidal activity. Indian Patent number 244427.

Wang, Y., Zhang, L., Li, Y., Liu, Y., Han, L., Zhu, Z., Wang, F. and Peng, Y. 2014. Expression of Cry1Ab protein in a marker-free transgenic $B t$ rice line and its efficacy in controlling a target pest, Chilosuppressalis (Lepidoptera: Crambidae). Environ Entomol, 43:528536.

Wong, E. Y., Hironaka, C. M. and Fischhoff, D. A. 1992. Arabidopsis thaliana small subunit leader and transit peptide enhance the expression of $B$. thuringiensis proteins in transgenic plants. Plant Mol. Biol.,20: 81-93.

Wu, J., Luo, X., Zhang, X., Shi, Y. and Tian, Y. 2011. Development of insectresistant transgenic cotton with chimeric TVip3A accumulating in chloroplasts. Transgenic Res., 20: 963-973.

Xia, H., Rong, L., Kai, X., Wang, W., Yang, X., Yang, C., Luo, J., Lai, F., Ye, W. and $\mathrm{Fu}, \mathrm{Q}$. 2011. Enhanced yield performance of $B t$ rice under targetinsect attacks: implications for field insect management. Transgenic Res, 20: 655-664.

Yang, Y.Y., Mei, F., Zhang, W., Shen,Z. and Fang,J. 2014. Creation of $B t$ rice expressing a fusion protein of Cry1Ac and CrylIlike using a green tissuespecific promoter. J. Econ. Entomol., 107(4):1674-1679.

Ye, G.Y., Yao, H.W., Shu, Q.Y., Cheng, X., Hu, C., Xia, Y.W., Gao, M.W. and Altosaar, I. 2003. High levels of stable resistance in transgenic rice with a crylAb gene from Bacillus thuringiensis Berliner to rice leaffolder, Cnaphalocrocis medinalis (Guenee) under field conditions. Crop Protection, 22: 171-178.

Ye, R., Huang, H., Yang, Z., Chen, T., Liu, L., Li, X., Chen, H. and Lin, Y. 2009. Development of insect-resistant transgenic rice with Cry1C-free endosperm. Pest Manag. Sci., 65: 10151020.

\section{How to cite this article:}

Rajadurai, G., S. Varanavasiyappan, N. Balakrishnan, V. Udayasuriyan, D. Sudhakar and Natarajan, N. 2018. Development of Transgenic indica Rice with a Chimeric cry2AXl Gene against Leaffolder, Cnaphalocrocis medinalis (Guenee). Int.J.Curr.Microbiol.App.Sci. 7(07): 3242-3253. doi: https://doi.org/10.20546/ijcmas.2018.707.378 